\title{
The Comparison of Agricultural Knowledge and Information Systems (Akis) For Adopters and Non-Adopters of Good Agricultural Practices in Bafra District of Samsun, Turkey
}

\author{
Mustafe Abdulkadir Abdurahman ${ }^{*}$, Kursat Demiryurek ${ }^{2}$, Nur Ilkay Abaci ${ }^{2}$ \\ ${ }^{1}$ Faculty of Agriculture, Gollis University, Hargeisa, Somaliland \\ ${ }^{2}$ Department of Agricultural Economics, Faculty of Agriculture, Ondokuzmayls University, 55139 Samsun, Turkey
}

\section{A R T I C L E I N F O}

\section{Article history:}

Received 02 June 2016

Accepted 14 November 2016

Available online, ISSN: 2148-127X

\section{Keywords}

Agricultural knowledge

Information systems

Good agricultural practices

Adoption

AKIS

"Corresponding Author:

E-mail: mustafe441@gmail.com

\section{A B S T R A C T}

The purpose of the study is to compare Agricultural Knowledge and Information Systems (AKIS) for adopters and non-adopters of Good Agricultural Practices (GAPs) in the Bafra district of Samsun, Turkey. The main materials of this study are the data obtained from a survey and interview with adopters and non-adopters of GAPs in Bafra district. The research data were collected from 77 farmers contained both adopters and non-adopters of GAPs. Statistical analysis, such as Chi-square and t-test was used. The study results presented the socio-economic characteristics of farmers. There was a significant difference between adopters and non-adopters of GAPs, according to household size, organizational membership, farm size, livestock and crop production. Meanwhile, the information sources such as a district agricultural manager/personnel, adviser of the farmers' union association (GAPs) and pesticide/fertilizer dealers were preferred the main sources of agricultural information for adopters of GAPs. However, it recommended that information sources like research institute, university and cooperatives needs to be improved by strengthening their way of information dissemination. In terms of usefulness of AKIS for this study, it seems that this system was insufficient to analyze this study. Even though the functions of this system are essent ial elements, they are insufficient for establishing a network of complex innovation-oriented institutional arrangements. In the future, this study suggests to analyze GAPs it needs to use Agricultural Knowledge and Innovation System (AKIS) approach, because this system have many interaction networks that can facilitate the researchers to reach the innovation easily to the intended farmers.

Türk Tarım - Gıda Bilim ve Teknoloji Dergisi, 4(12): 1092-1103, 2016

\section{İyi Tarım Uygulamalarını Benimseyen ve Benimsemeyen Çiftçilerin Tarımsal Yenilik ve Bilgi Sistemlerinin Karşılaştırılması: Samsun İli Bafra İlçesi Örneği}

\section{A K A L E B İ L G İ S İ}

Geliş 02 Haziran 2016

Kabul 14 Kasim 2016

Çevrimiçi baskı, ISSN: 2148-127X

Anahtar Kelimeler:

Tarimsal bilgi

Enformasyon sistemleri

İyi tarım uygulamaları

Benimseme

TBES

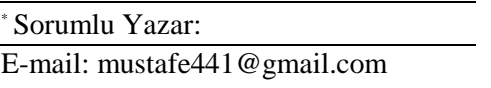

\section{Ö Z E T}

Çalışmanın amacı Samsun ili Bafra ilçesinde İyi Tarım Uygulaması (İTU) yapan ve yapmayan çiftçilerin Tarımsal Bilgi ve Enformasyon Sistemleri (TBES)'ni karşılaştırmaktır. Araştırmanın birincil ve temel materyalini Bafra ilçesinde İTU yapan ve yapmayan çiftçiler ile anket ve mülakat yoluyla elde edilen veriler oluşturmaktadır. Araştırma verileri ITU yapan ve yapmayan 77 çiftçiden toplanmışı̧ı. Verilerin analizinde tanımlayıcı istatistikler ile skorlar hesaplanmış ve uygun istatistiki testler yardımıyla karşılaştırılmıştır. Araştırma sonucunda İTU uygulayan ve uygulamayan çiftçiler arasında bazı sosyoekonomik, kişisel ve tarımsal işletme özellikleri açısından farklılıklar belirlenmiştir. Öte yandan, İTU'yu benimseyen çiftçilerin en çok yararlandığı enformasyon kaynakları olarak ilçe tarım müdürlüğü ve elemanları, sebze üreticileri birliği (ITU) danışmanı ve ilaç/gübre bayileri olarak belirlenmiştir. Ancak, araştırma enstitüsü, üniversite ve kooperatifler gibi enformasyon kaynaklarından çok sınırlı yararlanılmıştır. $\mathrm{Bu}$ yüzden bu kurumsal kaynakların çiftçileri daha fazla desteklemesi gerekmektedir. Bu çalışma sonucunda TBES teorisi ve metodolojisinin çitçilerin enformasyon sistemlerinin belirlenmesi için yetersiz olduğu düşünülmektedir. Çiftçileri destekleyen enformasyon kaynaklarının belirlenmesi bu sistemin temel unsuru olsa da; enformasyon ve yeniliklerin iletişimi, paylaşımı ve ağının belirlenmesi için TBES yaklaşımı yeterli değildir. $\mathrm{Bu}$ nedenle gelecekte İTU gibi çevreyi korumaya yönelik ve sınırlı enformasyon desteğinin olduğu karmaşı enformasyon ve bilgi sistemlerinin analizinde sosyal iletişim ağı analizleriyle Tarımsal Yenilik Sistemi (TYS) yaklaşımının kullanılması daha uygun olabilecektir. 


\section{Introduction}

The world in recent years, as in all areas has reached the point of international trade, the trade agreements in agriculture and food products sector determined by World Trade Organization 'WTO' according to their rules. Countries have faced with the agreement 'protection of human life and health' status as a principle in order to ensure food security concept (Akdamar, 2004). Therefore, people both in Turkey and other member states should apply these standards for commercial revenues. In this case, organic farming is being implemented in Turkey; to this end that Good Agricultural Practices (GAPs) and environmentally friendly systems such as sustainable agriculture should also be applied (Önen and Kara, 2008). To do so, the kind of production should be done in accordance with the demand of the major markets, controlled agriculture, good agricultural practices and consideration should be given to certified production.

Good Agricultural Practices (GAPs) is environmentally sound, economically viable and socially acceptable form of healthy and safe food and non-food agricultural products (FAO, 2003; Mushobozi and Santacoloma, 2010). At the same time, the Agricultural Knowledge and Information Systems (AKIS), production of agricultural products and natural resources, consists of system of information and knowledge between farmers' organizations and institutions that provide support for the management and marketing. Before AKIS, although there was weak relationship among other actors involved in this system, in recent years because of availability of AKIS system, farmers have sufficient time and information to get access to the knowledge and information they need. AKIS system also helps the farmers to understand the links among actors who are member in the system.

Figure 1GAPs are a practice that is important and necessary for increasing the income and profit of the farmers. Farmers who adopt these practices also consider the health of themselves and their families besides they pay attention to the environmental protection. GAPs made some changes the input and the products grown by the farmers. For example, the selection of chemical fertilizers is the last choice for adopters of GAPs, because GAPs offers new ways for the protection of products such as using biological control, pest-resistant products and cultural practices.

Combination and integration of AKIS and GAPs will be helping the farmers to obtain healthy and good quality food to assure their nutrition and nourishment, generating a value added in their products to access markets in a better way and consumers will enjoy better safe quality food, with sustainable production.

Today, regional environmental problems have become widespread globally. Therefore, GAPs and environmental awareness began to spread, and to avoid problems arising from agriculture. In this context, in Turkey (Hasdemir and Talug, 2012; Aydın et al., 2015; Sayın et al., 2015) and in different countries (Hobbs, 2003; Hongxu and Chengsuo, 2008) conducted GAPs and other related studies. Studies such as factors affecting the adoption of GAPs (Hasdemir and Talug, 2012), the analysis of the situation of adopters and non-adopters of GAPs (Aydin et al., 2015) have focused on such issues. Farmers influenced each other when they discussed in terms of decision-making on what to produce, so that the study of adopters of GAPs on AKIS has been revealed. Therefore, the purpose of this study is The Comparison of Agricultural Knowledge and Information Systems (AKIS) for Adopters and NonAdopters of Good Agricultural Practices (GAPs).

The main objective of this study related to comparison of agricultural knowledge and information systems (AKIS) for adopters and non-adopters of good agricultural practices (GAPs) in Bafra district. The study compares the utilization of informationrelated to adopters and non-adopters of GAPs. There are many reasons that farmers should understand the importance of Good Agricultural practices. GAPs protocols were developed in response to the increase in the number of outbreaks of foodborne diseases resulting from contaminated fresh produce. While most consumers associate food-borne diseases with improperly stored or poorly cooked animal products, it is clear that contaminated fruits and vegetables can also present a risk. Produce can become contaminated by any of a number of microbes (bacteria, viruses, parasites, or fungi) at any stage of production, processing, packaging, or marketing. While the cooking process would normally kill these microorganisms, fresh produce is often consumed raw and thus, at risk. Many researches related to food safety shows that the detection of residual pathogens prior to marketing. The basic objectives of this research are as follows:

- To identify the socio-economic characteristics of adopters and non-adoptersof good agricultural practices.

- To know the membership situation of adopters and non-adopters of GAPs infarmers' organizations.

- To examine the channels of information and sources of information dependence used by adopters of GAPs.

- To explore adopters and non-adopters of GAPs usage of information.

- To explore the adoption of new innovations of GAPs by adopters of GAPs.

\section{Research Questions}

Research questions causing the emergence of research are as follows:

- Are there differences in the socio-economic factors of adopters and nonadopters of GAPs?

- Are there differences of number of labor force required by adopters and nonadopters of GAPs?

- Are there differences participations in farmers' organizations for adopters and non-adopters of GAPs?

- Are there differences, challenges of source of information for adopters and non-adopters of GAPs?

- What are the reasons for rejecting the beginning of GAPs for non-adopters of GAPs (conventional farmers)?

- Are adopters of GAPs adopted the new innovations of good agricultural practices (GAPs)? 


\section{Research Hypothesis}

Research hypothesis are searching answers for the research questions before performing statistical analysis and using the previous research analysis and research results from a pilot study. Then the data obtained from farmers through questionnaire study will be conducted to test the relevant statistical methods. The alternative hypotheses of the thesis are as follows:

- There are differences in terms of socio-economic factors for adopters and nonadopters of GAPs.

- There are differences in the labor force (farm workers) required by adopters and non-adopters of GAPs.

- There is a difference of membership situation between adopters and nonadopters of GAPs in farmers' organizations.

- There are many channels of information and sources of information dependence used by adopters of GAPs.

- There are difference between adopters and nonadopters of GAPs for the usage of information.

- Adopters of (GAPs) adopted the new innovations from good agricultural practices (GAPs).

\section{Material and Method}

\section{Data Collection, Methods and Instruments}

The study used data obtained from survey and direct observations to collect as primary data. These multiple data collection techniques were used in order to increase the validity and reliability of the obtained. The research instrument was in the form of a questionnaire. Some of the questionnaire was like socio-economic information such as age, education level, agricultural experience, farm size, source of income (on-farm and off-farm income) and agricultural organization's membership status. There are nearly 150 adopters of GAPs and more than 1000 nonadopters of GAPs in Bafra district. 34 out of 150 of adopters of GAPs and 40 out of 1000 non-adopters of GAPs were identified as the purposeful and used as sample for the study. Purposive sampling was used to select the sample of the research. Purposive sampling, also known as judgmental, selective or subjective sampling, is a type of non-probability sampling technique. Nonprobability sampling focuses on sampling techniques where the units that are investigated are based on the judgment of the researcher. Fener, Agillar, Sarikoy and Orencik villages of Bafra district were selected for the study. Most of the adopters of GAPs were live Sarikoy and Agillar villages. While interviewing adopters of GAPs, there were also conventional farmers who live there. The study was not considered the population that lives in these villages. Approximately, 150 of adopters of GAPs and thousands of non-adopters of GAPs were living in the villages. Bafra district is one of the districts that many adopters of GAPs are live, and this was the reason the study was selected to analyze the adopters of GAPs that live in it. Additionally, there were also conventional farmers (nonadopters of GAPs) in the same area with adopters of GAPs. The questionnaire contains questions concerned both of the groups.

\section{Calculation of Total Information Scores}

According to Demiryürek (2008), information scores for each component of the farmers' agricultural information system can be calculated by multiplying the weights of information contact with degree of information usefulness. Following Demiryürek (2008), Total Information Score (TIS) is formulated as:

$$
T I S_{i j}=\sum_{i}^{j} F C_{i j} \times I U_{i j}
$$

Where FCij is the number of contacts with $j$-th information channel to the $\mathrm{i}$-th adopter of GAPs and IUij is the usefulness of $\mathrm{j}$-th information channel to the $\mathrm{i}$-th adopter of GAPs. The weights were given to each component according to the extent of information contact.

- The weight of 0 was given to no contact,

- 1 for once a year,

- 2 for two or three times a year,

- 4 for four or five times a year,

- 12 for once a month,

- 30 for two or three times a month,

- 52 for once a week,

- 130 for two or three times a week and

- 365 for information contacts once a day.

Similarly, the degree of usefulness of information sources was also weighted.

- The weight of 0 was given to not useful at all,

- 0.25 for little useful,

- 0.50 for somewhat useful,

- $\quad 0.75$ for useful and

- for very useful.

The scores were calculated on the basis of percentages of farmers' reporting each level of use of the sources.

\section{Statistical Analysis}

The data obtained through a survey, were made primarily on processed by Statistical Package for the Social Sciences (SPSS) program on the computer. Variables related to socio-economic aspects of adopters and non-adopters of GAPs farmers were compared and classified as parametric and non-parametric variables.

In the survey, questions related to most important factors for GAPs practices were asked and the important factors were environmental protection factors (soil, plant, animal and water protection), innovation (need for testing new and different things), health factors (protecting of the health of himself, his family, his workers and his consumers), economic factors (premium price, supports, save costs, profits etc.), and social factors ( company, union, other GAPs producers support etc.) respectively.

The survey data were analyzed using descriptive statistical tools including mean, frequency distributions and percentages. 


\section{Results and Discussion}

\section{Socio-economic Characteristics of Farmers}

Farming is a multi-disciplinary science, not only biotechnical and environmental factors, but also socioeconomic issues. Economic research assists both farmers and policy makers (Shang, 1994). Socio-economic examines social and economic factors to better understand how the combination of both influences something.

Age of the farmer sometimes effected decisionmaking about what to plant, when to plant, how to plant, and where to plant. If the farmer is an old farmer, he has a lot of experiences and those experiences helping him to grow what more productive, more available and more resistant to the pests. However, the small-scale farming system encounters sever structural problems, particularly the rapid ageing of the farmer population and the scarcity of young farmers entering the profession. The consequences of unsolved structural problems will hamper sustainable agricultural development (Ilbery et al., 1997).

The age-related structural crisis will lead to an array of agricultural development problems; in particular, farm productivity, market competitiveness, rural economic viability and food security will be under threat. These challenges related to the lack of generational renewal in the farming system should overcome to secure agricultural sustainability. Therefore, determining how to support young farmers is a political priority for the future agricultural policy regarding the small-holding farming, world (Hazell et al., 2007).

Table 1 presented that there was no statistical difference between the ages of adopters and non-adopters of GAPs farmers $(\mathrm{P}<0.05)$. It seems that age had not have relationship with the adoption of GAPs. This might because of the difference of age level. Older farmers who had experience on old fashioned practices were interested new way of farming practices.

This study supported by Aydoğan (2012) examined comparison of sources of communication and social network analysis for organic and conventional hazelnut growers in Terme and Çarşamba districts of Samsun province and found that there was no statistical difference between ages of organic and conventional hazelnut growers. Demiryürek et al. (2015) conducted research on effect of dairy cattle breeders' association membership on sustainability in Samsun province and found that there was no significant difference between members and nonmembers in terms of their age. Loan et al. (2015) examined the adoption of GAPs in the Lychee crop in Vietnam and found that the difference in age between adopters and non-adopters of GAPs was not significant. U - Rungsima Wong (2000) examined factors related to the adoption of Neem extracts use an insecticide in Thailand and found that age had no relationship with the adoption of farmers of the prevention of pests by using Neem extracts

Education is the production of desirable changes in knowledge (things known), attitude (things felt) and skills (things done), either in all (or) one or more of human behavior. Education is also the act or process of imparting or acquiring particularknowledge or skills, as for a profession. Extension Education is defined as an educational process to provide knowledge to the rural people about the improved practices in a convincing manner and help them to take a decision within their specific local conditions (Dahama, 1973). Education is an integral part of the extension. The basic concept of extension is that it is education. The extension means that type of education, which is stretched out, to the people in rural areas, beyond the limits of the educational institutions to which the formal type of education is normally confined. Extension education is primarily for the rural development. Its main objective is to bring necessary change in the beliefs or views of people. Extension education is an educational process by which capabilities among people are developed to understand their problems and resources. It is utilized to make scientific methods available to the rural people, so that they can raise their agricultural production and their standard of living. The results of the educational status of adopters and non-adopters of GAPs had given in Table 2.

Education of the farmer has been assumed to have a positive influence on the farmers' decision to adopt new technology. However, this study showed that there was no statistically difference between adopters and non-adopters of GAPs and it seems that education did not affect the adoption of GAPs $(\mathrm{P}<0.05)$. Demiryürek et al. (2015) conducted research on effect of dairy cattle breeders' association membership on sustainability in Samsun province and found that there was no significant difference between members and non-members in terms of their educational background.

In contrary to this study Okunlola et al. (2011) on adoption of new technologies by fish farmers and (Ajewole, 2010) on adoption of the technology of organic fertilizers in Nigeria found that the level of education had a positive and significant influence on the adoption of the technology.

Table 3 presented that there is a statistical difference between on-farm income of adopters and non-adopters of GAPs ( $P>0.05)$. The on-farm income of adopters was higher than the non adopters of GAPs. This might because adopters of GAPs got support and subsidies from the government. This subsidy seems to encourage the adopters of GAPs to continue to be an adopter of GAPs and also the higher income of them could be encouraged non-adopters to be adopters of GAPs.

Table 1 The age of farmers and the test results

\begin{tabular}{l|ccccc}
\hline \multicolumn{1}{c|}{ Mode of Production } & No. ofPerson & Average & Std. deviation & Min. & Max. \\
\hline Adopters of GAPs & 37 & 47.16 & 9.70 & 28 & 65 \\
Non-adopters ofGAPs & 40 & 49.98 & 12.54 & 24 & 80 \\
\hline
\end{tabular}


Table 2 Educational level of the respondents

\begin{tabular}{l|rrrr}
\hline \multirow{2}{*}{ Educational Level } & \multicolumn{2}{c}{ Adopters of GAPs } & \multicolumn{2}{c}{ Non-Adopters of GAPs } \\
\cline { 2 - 5 } & $\mathrm{N}$ & $\%$ & $\mathrm{~N}$ & $\%$ \\
\hline Primary & 25 & 67.56 & 26 & 65 \\
Intermediate & 7 & 18.91 & 10 & 25 \\
Secondary & 3 & 8.10 & 3 & 7.5 \\
Universty & 2 & 5.40 & 1 & 2.5 \\
Total & 37 & 100.00 & 40 & 100.00 \\
\hline
\end{tabular}

$\chi^{2}=0.767 ; \mathrm{df}=3 ; \mathrm{P}=0.857$

Table 3 The share of income from agricultural production system based on total revenues (\%)

\begin{tabular}{l|lcccc}
\hline \multicolumn{1}{c|}{ Production System } & $\mathrm{N}$ & Average (\%) & Std. Deviation & $\mathrm{t}$ value & $\mathrm{P}$ \\
\hline Adopters of GAPs & 37 & 85.95 & 24.32 & \multirow{2}{*}{2.674} & \multirow{2}{*}{0.009} \\
Non-Adopters of GAPs & 40 & 70.12 & 27.35 & \multirow{2}{*}{. } \\
\hline
\end{tabular}

In rural areas, farmers' organizations are the nearest and often only institutions providing essential goods and services to the rural poor and helping them break from the poverty cycle. Small farmers' income tends to fluctuate seasonally and this can easily tip them into poverty. By providing financial services, farmers' organizations reduce the risk individual farmers' face during seasonal shocks. Farmers' organizations also help mobilize capital and contribute to the growth of the local economy (URL$11)$.

When two or more people work together to achieve a group result, it is an organization. After the objectives of an organization are established, the functions that must be performed are determined. Personnel requirements are assessed and the physical resources need to accomplish the objectives determined. These elements must then be coordinated into a structural design that will help achieve the objectives. Finally, appropriate responsibilities are assigned (Montana et al., 1993).

Table 4 presented that there was a percentage difference between adopters $(51.4 \%)$ and non-adopters (48.6\%) of GAPs for the membership of Bafra Rice Producers' Union. There was a statistical difference between adopters and non-adopters of GAPs for the membership of Bafra Rice Producers' Union. In terms of Bafra Vegetable Producers' Union, all adopters of GAPs had a membership (100\%). This might be because of adopters of GAPs got the advice on GAPs principles from Bafra Vegetable Producer's Union. This association works to disseminate the information about GAPs. There was also a percentage difference between adopters (97.3) and non-adopters of GAPs $(2.7 \%)$ for the membership of Local Chambers of Agriculture (TZOB). All adopters of GAPs had a membership to Local Chambers of Agriculture (TZOB). The reason may be those chambers have the records of every farmer and it must be a member of it in order to be registered. In terms of membership of Irrigation Union it seems that both groups had a membership and this reason was to get the water for their farms. According to membership of Agricultural Sales Cooperatives, there was a statistical difference between adopters and nonadopters of GAPs $(\mathrm{P}<0.05)$. It implies that agricultural sales cooperatives had significant to both groups (adopters and non-adopters of GAPs). This might be because of information sharing and cooperation that exists in this group may have a benefit to them. The Agricultural Credit Cooperatives, there was no statistical difference between adopters and non-adopters of GAPs $(\mathrm{P}>0.05)$.

The membership status of farmers' associations can be explained by their satisfaction from these associations. Table 5 presents the satisfaction status of farmers. It compared satisfaction scores of all farmers' organizations. The highest score of satisfaction (466.65) got by Bafra Rice Producers' Union while the lowest score of satisfaction got by. Bafra Vegetable Producers' Union is the association disseminates the knowledge and practices of GAPs. This association got the seventh rank of satisfaction score (270.28). This might be because of nonadopters of GAPs were not a member of this association. The Bafra Vegetable Producers' Union provides consulting, training and extension services, technical support for harvesting, storage, and packaging of the products. It also rents a warehouse if necessary on behalf of themembers to store their products.

\section{GAPs}

Information and Knowledge Sources of adopters

An improved information and knowledge flow to, from, and within the agricultural sector are a key component in improving small-scale agricultural production and linking increased production to remunerative markets, thus leading to improved rural livelihoods, improving quality and yield, food security and national economies (Asaba et al., 2006). Farmers are always curious about what is new in the farming practices. When the farmers heard an innovation and its usefulness they started to adopt. For this reason getting the exact information about a new innovation was very important to farmers.

AKIS describe the exchange of knowledge and the services which support these exchanges in rural areas. As a system AKIS links people and organizations to promote mutual learning, to generate, share, and utilize agriculture-related technology, knowledge, and information. Components of an AKIS are diverse actors from the private, public and non-profit sectors relating to agriculture. The system may include the actors such as farmers, farm workers, agricultural educators, researchers, non-academic experts, public and independent private 
advisors, supply chain actors, and others in the agricultural sector. The public sector functions as a supplier of information, advice and funding for the agricultural sector and assures coordinating activities. Research and education sectors (both private and public) create knowledge and innovation, provide education and advisory services. The private sector also is one of the main parts of AKIS as many thousands of consultants from private sector operate either independently or as part of a large advisory organization (EU SCAR, 2013).

Figure 1 presented the sources of information and knowledge for adopters of GAPs. The bold arrows indicated the very important sources of information such as district manager/personnel, union adviser (GAPs) and pesticide/fertilizer dealers for adopters of GAPs. The narrow arrows indicated the important and less important sources of information for adopters of GAPs. The information and knowledge are very important for adopters of GAPs. To access this information and knowledge, it needs information transfer actors that transfers significant information from its sources to the adopters of GAPs. It was expected that family members and fellow farmers were the main source of information for adopters of GAPs. However, the study findings showed that district agricultural manager/personnel were the main sources of agricultural knowledge and information of GAPs in Bafra, with a percentage of $81 \%$, followed by union adviser (GAPs) $54 \%$ and pesticide/fertilizer dealers 45.9 as shown in Figure 2. This might because of pesticide/fertilizer dealers are input suppliers of pesticide and fertilizer for adopters of GAPs. District manager/personnel works as extension agents and maybe he usually had given advice and conduct trainings to the adopters of GAPs and this is reason became the main source of information and knowledge for adopters of GAPs. The study, supported by Rees et al (2000) examined AKIS in Kenya and found that government extension agents were the main source of information and knowledge for the farmers. However, Demiryürek (2000) conducted research on analysis of information systems for organic and conventional hazelnut producers in Samsun province and found that agricultural extension agents were not the main sources of information and knowledge to the farmers because agents organized no training activities in the villages.

Table 4 Production system based on membership status of farmers' organizations

\begin{tabular}{l|lrr}
\hline \multicolumn{1}{c|}{ Farmers' Organizations } & \multicolumn{1}{c}{ Mode of Production } & Membership (\%) & Non-Membership (\%) \\
\hline \multirow{2}{*}{ Rice Producers'Union } & Adopters of GAPs & 51.4 & 48.6 \\
& Non-Adopters of GAPs & 15.0 & 85.0 \\
\hline \multirow{2}{*}{ Vegetable Producers' Union } & Adopters of GAPs & 100.0 & 0.0 \\
& Non-Adopters of GAPs & 0.0 & 100.0 \\
\hline \multirow{2}{*}{ Local Chambers of Agriculture (TZOB) } & Adopters of GAPs & 97.3 & 2.7 \\
& Non-Adopters of GAPs & 70.0 & 30.0 \\
\hline \multirow{2}{*}{ Irrigation Union } & Adopters of GAPs & 56.8 & 43.2 \\
& Non-Adopters of GAPs & 40.0 & 60.0 \\
\multirow{2}{*}{ Agricultural Sales Cooperatives } & Adopters of GAPs & 73.0 & 27.0 \\
& Non-Adopters of GAPs & 52.5 & 47.5 \\
\hline \multirow{2}{*}{ Agricultural Credit Cooperatives } & Adopters of GAPs & 78.4 & 21.6 \\
& Non-Adopters of GAPs & 72.5 & 27.5 \\
\hline \multirow{2}{*}{ Cattle Breeding Union } & Adopters of GAPs & 56.8 & 37.5 \\
\hline
\end{tabular}

Table 5 Production system based on satisfaction status of farmers' organizations

\begin{tabular}{|c|c|c|c|c|}
\hline Farmers' Organizations & Mode of Production & Satisfaction Score & Total Score* & Rank \\
\hline Rice Producers'Union & $\begin{array}{l}\text { Adopters of GAPs } \\
\text { Non-Adopters of GAPs }\end{array}$ & $\begin{array}{l}232.44 \\
234.21\end{array}$ & 466.65 & 1 \\
\hline Local Chambers of Agriculture (TZOB) & $\begin{array}{l}\text { Adopters of GAPs } \\
\text { Non-Adopters of GAPs }\end{array}$ & $\begin{array}{l}245.07 \\
215.00\end{array}$ & 460.07 & 2 \\
\hline Irrigation Union & $\begin{array}{l}\text { Adopters of GAPs } \\
\text { Non-Adopters of GAPs }\end{array}$ & $\begin{array}{l}208.12 \\
220.00\end{array}$ & 428.12 & 3 \\
\hline Agricultural Credit Cooperatives & $\begin{array}{l}\text { Adopters of GAPs } \\
\text { Non-Adopters of GAPs }\end{array}$ & $\begin{array}{l}254.08 \\
167.50\end{array}$ & 421.58 & 4 \\
\hline Agricultural Sales Cooperatives & $\begin{array}{l}\text { Adopters of GAPs } \\
\text { Non-Adopters of GAPs }\end{array}$ & $\begin{array}{l}235.15 \\
161.56\end{array}$ & 396.71 & 5 \\
\hline Cattle Breeding Union & $\begin{array}{l}\text { Adopters of GAPs } \\
\text { Non-Adopters of GAPs }\end{array}$ & $\begin{array}{l}100.00 \\
199.60\end{array}$ & 299.6 & 6 \\
\hline Vegetable Producers' Union & $\begin{array}{l}\text { Adopters of GAPs } \\
\text { Non-Adopters of GAPs }\end{array}$ & $\begin{array}{r}270.28 \\
-\end{array}$ & 270.28 & 7 \\
\hline
\end{tabular}

*Total score $=$ frequency $(\%) \mathrm{x}$ weight 


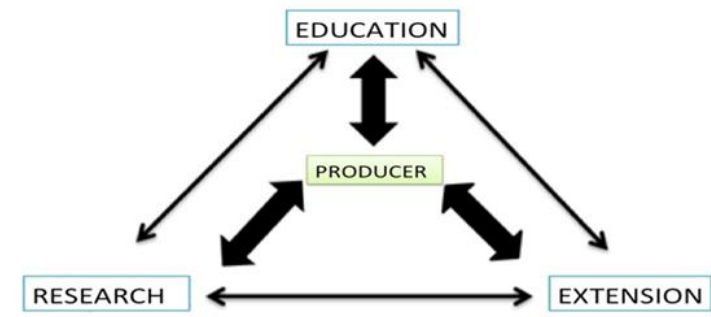

Figure 1 Agricultural Knowledge and Information Systems- AKIS (Rivera et al., 2005)

The adoption by farmers of good agricultural practices (GAPs), that favoring the environment and assure food quality and safety, is being a frequent fact. The increasing needs of food quality and safety of consumers, and the social concern for environmental quality and sustainable development, are inducing the agri-food industry in general and the vegetable industry in particular, to increase the qualityachievements and control in all phases of the production and marketing process, from farmer to retailer. The extent to which adopters of GAPs adopt available innovation and the speed by which they do so determines the impact of innovation in terms of productivity growth (Paul et al., 2003).

Table 6 presented environmental protection factors (protection of soil, livestock/animals, plants, and water) innovation (desire to try new or different things), economic factors (premium price, guaranteed of purchase, supports, save costs, profitability.), social factors (company, union, support from other GAPs producers) and health factors (protection of himself, his family, his employees and his consumer health). The environmental factors (soil, livestock/animals, plants, and water protection) were the most effective factors that induced farmers to adopt GAPs and most of the adopters of GAPs have a greater environmental concern and tendency than other groups to adopt the GAPs system. Adopters of GAPs also agree and comply with food safety and standard requirements of importing countries. The second most effective factors that farmers responded were health factors (protection of himself, his family, his employees and his consumer health). GAPs encourage farmers to produce food that is not only wholesome (promoting good health and well-being) and nutritious, but also safe. Adopters of GAPs take great pride in growing high quality, nutritious fruits and vegetables and would never knowingly produce food that could harm their customers. Good agriculture practices (GAPs) came with new innovations (desire to try new or different things). Innovation is an idea, practice or object that is perceived as new by an individual or other unit of adoption (Rogers, 2003).

Innovation is a third most effective factor related to adoption of GAPs. Economic factors (premium price, guaranteed of purchase, supports, save costs, profitability.) were also related to the adoption of GAPs. Interestingly, economic factors were less important than innovation. Social factors (company, union, and support from other GAPs producers) were least important in terms of adopting of GAPs. This might because of poor communication between the unions and adopters of
GAPs. This was identified that there was a need to improve and strength the information transfer of adopters of GAPs and their stakeholders. However, Demiryürek (2000) conducted research on analysis of information systems for organic and conventional hazelnut producers in Samsun province and found that economic factors (especially premium price and market guarantee) were the most important factors related to adopting of organic farming.

Conventional farming (agriculture) is an intensivetype of farming through the application of high-input systems that offer an increased yield. This term is broadly used in the international literature to describe intensive farming (Pacini et al., 2003).

Over the last two decades, attention in industrialized countries has focused on reducing pollution by fertilizers and synthetic pesticides in conventional agriculture. The concern of society for the environmental problems caused by conventional farming, in combination with increased demand for achieving sustainability in the agricultural sector and for safe, high-quality foodstuffs, has led to the emergence of alternative farming systems in recent year (Parra-Lopez et al., 2007). Conventional farming is a mix of agronomic techniques, some of those quite similar to the organic ones. It could be considered as the most widespread production system in any country, or as well, all the other kind of productive techniques which can be considered as alternatives to the organic ones (Offermann and Nieberg, 2000).

Table 7 presented reasons for rejecting good agricultural practices (GAPs) by conventional farmers. Conventional farmers misuse fertilizers and pesticides for the farm and that misuse, mostly caused environmental and soil problems. To be a conventional farmer, it means to do whatever makes your farm more productive and not caring of the food safety and quality, environment and even the health of the farmer himself. It indicated that conventional farmers were more depending on use of fertilizers (chemical fertilizers) and synthetic pesticides. Those were the reasons to reject adoption of GAPs. Another most effective to reject the adoption of GAPs was no without pesticides. This might be because of believing that without using fertilizers, their production could be low. These farmers were accustomed used of fertilizers and pesticides. They need to get information about GAPs and also that GAPs recommend farmers use manure fertilizers and as a pesticide should use suitable pesticides, and cultural practices. Another reason for not adopted GAPs by conventional farmers was that they responded GAPs was not profitable. It seems that this is one of the misconceptions believing by conventional farmers and maybe this was caused poor communication and lack of knowledge about GAPs. In term premium price, most of the conventional farmers complained about that GAPs provide less premium pricing to adopters of GAPs. So if there was less Premium pricing, it needs to increase the premium price for adopters of GAPs. The study, supported by Demiryürek (2000) conducted research on analysis of information systems for organic and conventional hazelnut producers in Samsun province and found that conventional producers were accustomed to using of chemicals, and related the yield directly to the 
use of chemicals.

According to Oladele (2006), the role of information for agriculture cannot be over emphasized in enhancing the agricultural development. Information is crucial for increasing agricultural production and improving marketing and distribution strategies. The use of information in agriculture sector is enhancing farming productivity in a number of ways (Bachhav, 2012). Providing information on weather trends, best practice in farming, timely access to market information helps farmer make correct decisions about what crops to plant and where to sell their product and buy inputs.

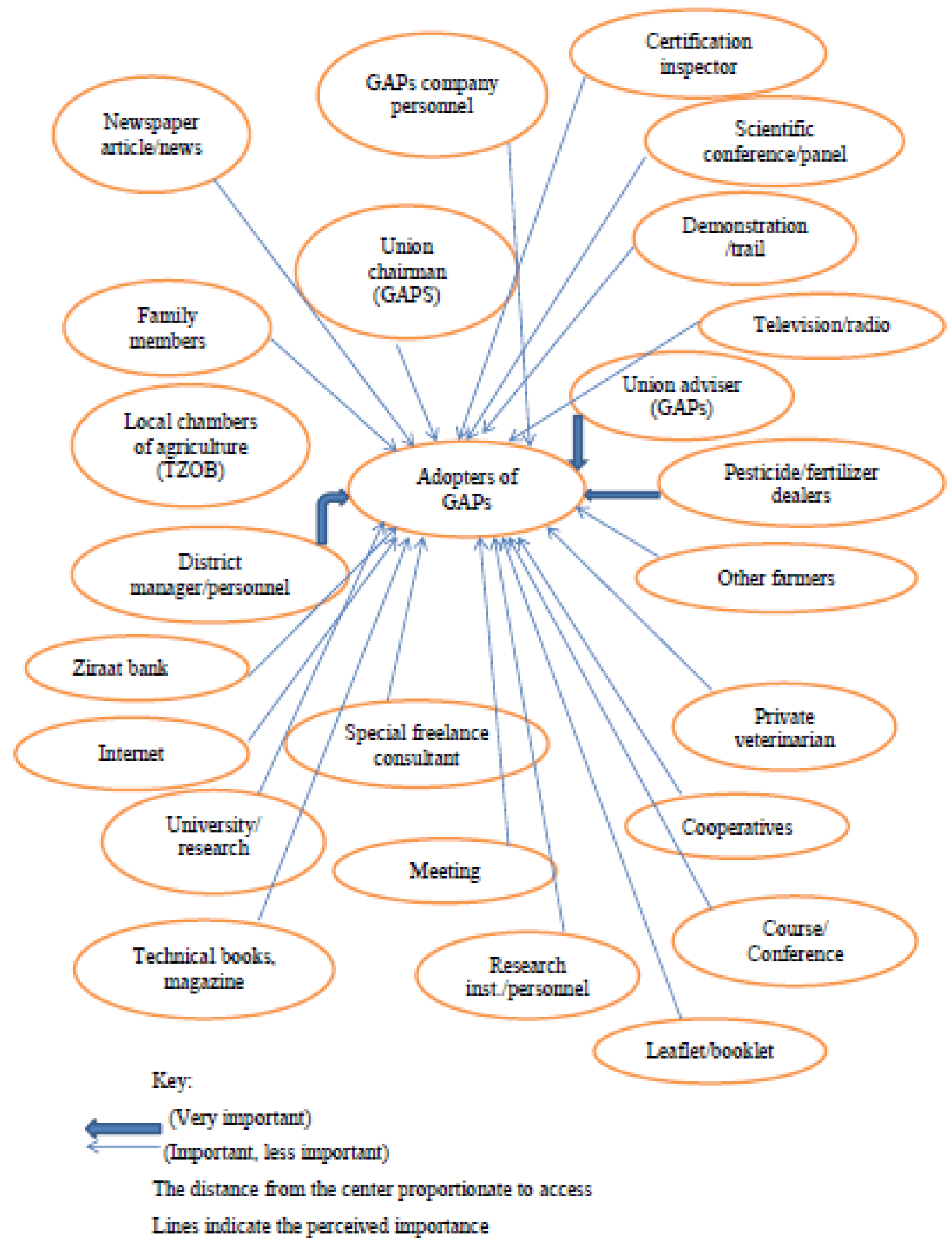

Figure 2 Concept map for agricultural information of adopters of GAPs 
Table 6 Main factors related to the adoption of GAPs

\begin{tabular}{l|ccrrr}
\hline \multicolumn{1}{c}{ Types of Factors } & $\begin{array}{c}\text { It was not effective } \\
(0)\end{array}$ & $\begin{array}{c}\text { Least Effective } \\
(1)\end{array}$ & $\begin{array}{c}\text { Most effective } \\
(2)\end{array}$ & $\begin{array}{c}\text { Total } \\
\text { score* }\end{array}$ & Rank \\
\hline Environmental protection factors & - & 21.2 & 145.5 & 166.7 & 1 \\
Health factors & - & 48.5 & 84.5 & 133.0 & 2 \\
Innovation & - & 61.3 & 64.5 & 125.8 & 3 \\
Economic factors & - & 57.2 & 64.3 & 121.5 & 4 \\
Social factors & - & 59.3 & 14.8 & 74.1 & 5 \\
\hline
\end{tabular}

*Total score $=$ frequency $(\%) \mathrm{x}$ weight; Environmental = (protection of soil, livestock/animals, plants and water); Health $=($ protection of himself, his family, his employees, and his consumers); Innovation = (desire to try new or different things); Economic = (premium prices, market guarantee, support, save costs, and profitability); Social = (company, union, support from other GAPs producers)

Table 7 Reasons for rejecting the beginning of GAPs (for conventional farmers)

\begin{tabular}{|c|c|c|c|c|c|}
\hline Reasons for Rejecting GAPs & $\begin{array}{c}\text { It was not effective } \\
(0)\end{array}$ & $\begin{array}{c}\text { Least effective } \\
\text { (1) }\end{array}$ & $\begin{array}{c}\text { Most effective } \\
\text { (2) }\end{array}$ & $\begin{array}{c}\text { Total } \\
\text { score* }\end{array}$ & Rank \\
\hline Not without fertilizers & - & 5.2 & 189.8 & 195.0 & 1 \\
\hline Not without pesticides & - & 7.7 & 184.6 & 192.6 & 2 \\
\hline Not profitable & - & 20.5 & 138.5 & 159.0 & 3 \\
\hline Less Premium Pricing & - & 41.1 & 97.5 & 138.6 & 4 \\
\hline GAPs facilitators $* *$ & - & 38.5 & 80.0 & 118.5 & 5 \\
\hline Low yield & - & 84.6 & 30.8 & 115.4 & 6 \\
\hline No goverment support & - & 18.0 & 80.0 & 98.0 & 7 \\
\hline Inadequate Labor & - & 46.2 & 30.8 & 77.0 & 8 \\
\hline Do not trust company & - & 46.2 & 20.5 & 66.7 & 9 \\
\hline Do not know & - & 31.6 & 26.4 & 58.0 & 10 \\
\hline Insecure traders & - & 41.1 & 10.3 & 51.4 & 11 \\
\hline Owed to the merchant & - & 38.5 & 5.1 & 43.6 & 12 \\
\hline Lack of capital & - & 30.8 & 10.3 & 41.1 & 13 \\
\hline Family objections & - & 25.7 & - & 25.7 & 14 \\
\hline Barrier property owner & - & 10.3 & - & 10.3 & 15 \\
\hline
\end{tabular}

*Total score $=$ frequency $(\%) \mathrm{x}$ weight; ${ }^{* *}$ Conv. farmers not invited by GAPs facilitators

Table 8 Adopters and non-adopters of GAPs information usage

\begin{tabular}{|c|c|c|c|c|}
\hline Mode of Production & Usefulness & $\begin{array}{l}\text { Appropriateness } \\
\text { Scores }\end{array}$ & $\begin{array}{c}\text { Total } \\
\text { score* }\end{array}$ & Rank \\
\hline $\begin{array}{l}\text { Adopters of GAPs } \\
\text { Non-Adopters of GAPs }\end{array}$ & $\begin{array}{l}\text { I would apply innovationafter testing and seeing } \\
\text { its usefulness. }\end{array}$ & $\begin{array}{l}257.0 \\
212.5\end{array}$ & 469.5 & 1 \\
\hline $\begin{array}{l}\text { Adopters of GAPs } \\
\text { Non-Adopters of GAPs }\end{array}$ & $\begin{array}{l}\text { I would apply afterconsultation with experts or } \\
\text { knowing innovation. }\end{array}$ & $\begin{array}{l}230.0 \\
192.5\end{array}$ & 422.5 & 2 \\
\hline $\begin{array}{l}\text { Adopters of GAPs } \\
\text { Non-Adopters of GAPs }\end{array}$ & $\begin{array}{l}\text { I would apply innovationafter other farmers tested } \\
\text { and it becomes successful. }\end{array}$ & $\begin{array}{l}219.0 \\
195.0\end{array}$ & 414.0 & 3 \\
\hline $\begin{array}{l}\text { Adopters of GAPs } \\
\text { Non-Adopters of GAPs }\end{array}$ & $\begin{array}{l}\text { I would apply directly the knowledge and } \\
\text { innovation that I hear from an expert. }\end{array}$ & $\begin{array}{l}154.1 \\
217.5\end{array}$ & 371.6 & 4 \\
\hline $\begin{array}{l}\text { Adopters of GAPs } \\
\text { Non-Adopters of GAPs }\end{array}$ & $\begin{array}{l}\text { I would apply innovationafter changing a little bit, } \\
\text { because my workingconditions are special for me. }\end{array}$ & $\begin{array}{l}167.8 \\
175.0\end{array}$ & 342.8 & 5 \\
\hline $\begin{array}{l}\text { Adopters of GAPs } \\
\text { Non-Adopters of GAPs }\end{array}$ & $\begin{array}{l}\text { I would apply informationrelated to my own } \\
\text { experience and existing applications. }\end{array}$ & $\begin{array}{r}154.3 \\
92.5 \\
\end{array}$ & 246.8 & 6 \\
\hline $\begin{array}{l}\text { Adopters of GAPs } \\
\text { Non-Adopters of GAPs }\end{array}$ & I would meet all information that I need. & $\begin{array}{r}113.7 \\
55.0\end{array}$ & 168.7 & 7 \\
\hline
\end{tabular}

*Total score $=$ frequency $(\%) \times$ weight

Table 8 presented the comparison of GAPs and nonadopters of GAPs information usage. The majority of adopters and non-adopters responded that 'They would apply innovation after testing and seeing its usefulness' with a score of (469.5). This might be because of believing that after testing the new innovation and saw its usefulness for them, then they can begin to adopt it. They also responded in high a number that 'They would apply after consultation with experts or knowing innovation' with a score of (422.5). This means that if they had a knowledge for innovation or they got advice from an expert, then they can apply this innovation. With a score (414), adopters and non-adopters responded that 'They also would apply innovation after other farmers tested and it becomes successful. The imitation behavior is what every farmer has on his mind. If he saw a good practice or innovation that done by his fellow farmer in his field as practical, then mostly it seems that he can decide to adopt 
the new innovation. The adopters and non-adopters responded that 'They would apply innovation after changing a little bit, because their working conditions are special for them' were also presented. This might be because of their confidence to ensure to test the new innovation before adopting it. The lowest score they responded was that 'They would meet all information that they need' with a score of (168.7). It seems that they cannot meet all information they need because the information comes from different sources and stakeholders. Although the stakeholders of adopters of GAPs and non-adopters were somewhat different, both groups were very interested to get the latest information regarding new techniques of farming, new methods of cultivation, new crops, seeds, pesticides, the water management, marketing of the product, government policies regarding agriculture, the export potential of their crops and the information about allied activities like fish farming, apiculture, poultry, dairy, and weather information on local and regional levels. Demiryürek (2000) conducted research on analysis of information systems for organic and conventional hazelnut producers in Samsun province and found that organic and conventional hazelnut producer did trials on using inputs, production techniques and pest control methods in order to test, observe and evaluate their applicability before they used them in their farming systems.

Information is an important factor in agriculture and it is the basis of extension service delivery. It is defined by Adereti et al, (2006) as data that have been put into a meaningful and useful context which is communicated to a recipient who uses it to make decisions. According to Demiryürek et al. (2008), found that agricultural information is an important factor that interacts with other production factors. The productivity of these other factors, such as land, labor, capital and managerial ability, can arguably be improved by relevant, reliable and useful information. Information supplied with extension, research, education and agricultural organizations help farmers make better decisions. Therefore, there is a need to understand the functioning of a particular agricultural information system in order to manage and improve it. Information within the hands of the farmers means empowerment through control over their resources and decision-making processes. They noted that being an effective and efficient delivery system of essential information and technology services facilitates the clients' critical role in decision-making towards improved agricultural production, harvesting, and packaging, processing, trading, and marketing (Maningas et al, 2005).

In table 9 compared the types of information needed by adopters of GAPs. Educational extension was getting the first rank with a total score of (304.4); it means that adopters of GAPs need most the information of educational extension. Educational extension was means of providing training and services to adopters of GAPs. Know-how (Input and Method) with a total score (296.6), was the second important information needed by adopters of GAPs. This implies that there was a need for technical information. Technical information is the information about land preparation, seed selection, planting, and harvesting. The third information needed by adopters of GAPs was the marketing information with a total score of 275.1. The marketing information influences the decision making of adopters of GAPs. Access to marketing information by adopters of GAPs, it helps them to know the situation of the market, the supply and demand of the market. So if the adopters of GAPs had information about the situation of the market, that the market need more supply, then they can decide to produce more and meet the supply requirement of the market. Other information presented were also information needed by producers. In terms of adopters of GAPs educational extension information was main information needed by them. However, Aydoğan (2012) examined comparison of sources of communication and social network analysis for organic and conventional hazelnut growers in Terme and Çarşamba districts of Samsun province and found that information about subsidies was the main information needed by organic producers.

The aim of the study was the Comparison of Agricultural Knowledge and Informatin Systems (AKIS) for Adopter and Non-Adopters of Good Agricultural Practices (GAPs). Adopters of GAPs were environmentally sound, they concerned about the environment. Their production was increased by GAPs practices. Although their produciton needs to inform consumers by government, they benefit from the use of GAPs. Non-adopters of GAPs were not considered the environment, and they use any chemical fertilizers that they thought which protects their crops. The poor information system in the area also caused the misconceptions of non- adopters of GAPs about GAPs.

Table 9 Comparison of types of information needed by adopters of GAPs

\begin{tabular}{l|rrrrrr}
\hline The types of information (weight) & $\begin{array}{c}\text { Very much } \\
(4)\end{array}$ & $\begin{array}{c}\text { Much } \\
(3)\end{array}$ & $\begin{array}{c}\text { Some } \\
(2)\end{array}$ & $\begin{array}{c}\text { Few } \\
(1)\end{array}$ & $\begin{array}{c}\text { Total } \\
\text { score* }\end{array}$ & Rank \\
\hline Educational Extension & 173.9 & 104.4 & 17.4 & 8.7 & 304.4 & 1 \\
Know-how (Input and Method) & 211.2 & 61.8 & 17.7 & 5.9 & 296.6 & 2 \\
Marketing & 216.5 & 37.5 & 16.7 & 4.2 & 275.1 & 3 \\
Own experience & 63.2 & 173.9 & 31.6 & 5.3 & 274.0 & 4 \\
Subsidies & 123.3 & 63.2 & 31.6 & 10.5 & 228.6 & 5 \\
Legal official regulations & 114.3 & 53.6 & 50.0 & 7.2 & 225.1 & 6 \\
Diversification of production & 66.7 & 112.5 & 16.7 & 12.5 & 208.4 & 7 \\
Price & 64.0 & 108.0 & 8.0 & 8.0 & 188.0 & 8 \\
Private consultancy gardener & 42.1 & 63.2 & - & 10.5 & 115.8 & 9 \\
Private adviser & 25.8 & 48.4 & 12.9 & 3.3 & 90.4 & 10 \\
\hline
\end{tabular}

*Total score $=$ frequency $(\%) \mathrm{x}$ weight 


\section{Conclusion}

The aim of the study was the Comparison of Agricultural Knowledge and Informatin Systems (AKIS) for Adopter and Non-Adopters of Good Agricultural Practices (GAPs). Adopters of GAPs were environmentally sound, they concerned about the environment. Their production was increased by GAPs practices. Although their produciton needs to inform consumers by government, they benefit from the use of GAPs. Non-adopters of GAPs were not considered the environment, and they use any chemical fertilizers that they thought which protects their crops. The poor information system in the area also caused the misconceptions of non- adopters of GAPs about GAPs.

The most important reason that adopters of GAPs to adopt GAPs was to receive GAPs support from the government. Adopters of GAPs adopt and sustain GAPs practices, although, they could not sell their GAPs products with high premium (They sell like conventional product). The environmental factors (protections of soil, plants, livestock/animals and water) were also the most effective factors that induced farmers to adopt GAPs and most of the adopters of GAPs have a greater environmental concern and tendency. Health factors (protection of himself, his family, his employees and his consumer health) were also effective factors. GAPs encourage farmers to produce food that is not only wholesome (promoting good health and well-being) and nutritious, but also safe. Adopters of GAPs take great pride in growing high quality, nutritious fruits and vegetables and would never knowingly produce food that could harm their customers.

\section{Knowledge}

This study took place in oral presentations at the XII. National Agricultural Economics Congress.

\section{References}

Adereti FO, Fapojuwo OE. Onasanya AS. 2006. Information utilization on cocoa production techniques by farmers in Oluyole Local Government area of Oyo State, Nigeria. European J. Soc. Sci, 3(1): 1-7.

Ajewole OC. 2010. Farmers response to adoption of commercially available organic fertilizers in Oyo state, Nigeria. African Journal of Agricultural Research, 5(18): 2497-2503.

Akdamar M. 2004. Dünyada İyi Tarım Uygulamaları ve Gerekçeleri. Türk Tarım Dergisi, 157: 38-39.

Asaba JF. Musebe R. Kimani M. Day R. Nkonu M. Mukhebi A. Wesonga A. Mbula R. Balaba P, Nakagwa A. 2006. Bridging the information and knowledge gap between urban and rural communities through rural knowledge centres: case studies from Kenya and Uganda. International Association of Agricultural Information Specialists (IAALD) Quarterly Bulletin, Vol. 51: 3-4.

Aydın B. Özkan E. Aktürk D. Kiracı MA. Hurma H. 2015. Kırklareli, Edirne, Tekirdağ ve Çanakkale İllerinde Üreticilerin İyi Tarım Uygulamalarına Yaklaşımı. Tarım Ekonomisi Araştırmaları Dergisi, 1(2).

Aydoğan M. 2012. Comparison of sources of communication and social network analysis for organic and conventional hazelnut growers in Terma and Çarşamba districts of Samsun province, Turkey. Master's thesis, Ondokuz Mayis University.
Bachhav NB. 2012. Information needs of the rural farmers: A study from Maharashtra, India: A survey. Library Philosophy and Practice.

Dahama OP. 1973. Extension and Rural Welfare, Ram Prasad and Sons, Agra.

Demiryürek K. 2000. The Analysis of Information Systems for Organic and Conventional Hazelnut Producers in Three Villages of the Black Sea Region, Turkey, Published PhD Thesis, The University of Reading, UK, OMÜ Ziraat Fakültesi Basımevi, pp 301+ xvii, Samsun.

Demiryürek K. Erdem H. Ceyhan V. Atasever S. Uysal O. 2008. Agricultural Information System and Communication Networks: The Caseof Dairy Cattle Farmers in Samsun Province of Turkey. InformationResearch 13: 343.

Demiryürek K. Abaci NI. Abaci, SH. Atasever S, Erdem H. 2015. Effect of Dairy Cattle Breeders' Association Membership on Sustainability of Innovations in Samsun Province, Turkey.

Diao X. Hazell PB. Resnick D, Thurlow J. 2007. The role of agriculture in development: Implications for Sub-Saharan Africa (Vol. 153). Intl Food Policy Res Inst.

EU SCAR. 2013. Agricultural knowledge and innovation systems towards 2020 an orientation paper on linking innovation and research, Brussels. http://ec.europa.eu/ research/agriculture/scar/groups_en.htm

FAO. 2003. http://www.fao.org/docrep/013/i1645e/ i1645e00.pdf [Erişim: 05 Eylül 2015]

Hasdemir M, Talug C. 2012. Kiraz Yetiştiriciliğinde İyi Tarım Uygulamalarının Benimsenmesini Etkileyen Faktörlerin Analizi. Derim, 29(1): 23-36.

Hobbs JE. 2003. Incentives for the Adoption of Good Agricultural Practices (GAPs). Food and Agriculture Organization.

Hongxu SUN, Chengsuo YU. 2008. Discussion on the Development of Good Agricultural Practice. J. Agricultural Science \& Technology and Equipment, 4: 038.

Ilbery B. Healy M. Higginbottom J. Chiotti Q, Rickard T. 1997. On and off-farm business diversification by farm households in England. In Agricultural restructuring and sustainability: a geographical perspective. (pp. 135-151). CAB INTERNATIONAL.

Loan L. Isabelita MP. Salvador PC, Zenaida MS. 2015. Adoption of Good Agricultural Practices (VietGAP) in the Lychee Industry in Vietnam, Asian Journal of Agricultural Extension, Economics \& Sociology 8(2):1-12, 2016; Article No. AJAEES.19948 ISSN: 2320-7027

Maningas RV. Perez VO. Macaraig AJ. Alesna WT, Villagonzalo J. 2015. Electronic Information Dissemination through the Farmers' Information and Technology Services (FITS)/Tchno Pinoy Program. Bringing Information and Technology within the Reach of the Farmers. From http://jsai.or.jp/afita/afita-conf/2000/part08/p231.pdf, 2000.

Mushobozi WL. Santacoloma P. 2010. Good Agricultural Practices (GAP) on horticultural production for extension staff in Tanzania. FAO GAP Working Papers Series (FAO).

Montana P, Charnow B. 1993. Management: A Streamlined Course for Students and Business People. (Hauppauge, New York: Barron's Business Review Series, 1993, pp. 155-159.

Offermann F, Nieberg H. 2000. Profitability of organic farming in Europe. In IFOAM 2000-The World Grows Organic, Proceedings 13th International IFOAM Scientific Conference, Basel 28-31 August 2000 (pp. 666-669). VDF Hochschulverlag.

Okunlola JO. Oludare AO, Akinwalere BO. 2011. Adoption of new technologies by fish farmers in Akure, Ondo state Nigeria. Journal of Agricultural Technology, 7(6): 15391548.

Oladele OI. 2006. A Tobit analysis of propensity to discontinue adoption of agricultural technology among farmers in Southwestern Nigeria. Journal of Central European Agriculture, 6(3): 249-254. 
Önen H, Kara K. 2008. Organik Tarım. Ed. Serin, Y., Yem Bitkileri ve Meraya Dayalı Hayvancılık Eğitimi. Erciyes Üniversitesi Yayınları No:60, Kayseri, 472-475.

Pacini C. Wossink A. Giesen G. Vazzana C, Huirne R. 2003. Evaluation of sustainability of organic, integrated and conventional farming systems: a farm and field-scale analysis. Agriculture, Ecosystems \& Environment, 95(1): 273-288.

Parra-Lopez C. De-Haro-Giménez T, Calatrava-Requena J. 2007. Diffusion and adoption of organic farming in the southern Spanish olive groves. Journal of Sustainable Agriculture, 30(1): 105-151.

Paul D Haris Van M. Arjan W, Katarzyna B. 2003. Innovation Adoption in Agriculture: Innovators, Early Adopters and Laggards. Available on: http://www.iran.fr.diederen.pdg Accessed in July 2012.

Rees D. Momanyi M. Wekundah, J. Ndungu F. 2000. Agricultural Knowledge and Information Systems in Kenya-Implications for Technology Dissemination and Development. Agricultural Research \& Extension Network, Network Paper 107.
Rogers E. 2003. Diffusion of innovations, Free Press, A Division of Simon \& Schuster, Inc., New York.

Sayın B. Çelikyurt MA. Kuzgun M. Aydın B. 2015. Antalya ilinde örtüaltı yetiştiriciliği yapan üreticilerin iyi tarım uygulamalarına yaklaşımı. Derim, 32(2): 171-186.

Shang YC. 1994. Closing remarks. Socio-economic Aqauculture. Proceedings of International Symposium 93 4, 376-379. Taiwan.

U-rungsimawong P. 2000. Factors Related to the Adoption of Neem Extracts Use as an Insecticide: A Case Study of Farmers in Muang District, Nakhon Pathom Province, Unpublished M.Sc. Research Paper, National Institute Development Administration, Thailand.

URL-11. Sustainable Agriculture and Rural Development (SARD) Policy Brief 12 ftp://ftp.fao.org/sd/sda/ sdar/sard/SARD-farmers-orgs\%20-\%20english.pdf (Date of access: 15.10.2015) 